\title{
PENGEMBANGAN E-BOOKLET BERBASIS WEB SEBAGAI BAHAN AJAR PEMBELAJARAN IPS KELAS V
}

\author{
Devi Asinta, Fitria Dwi Prasetyaningtyas \\ Universitas Negeri Semarang, Universitas Negeri Semarang \\ deviasinta50@gmail.com, fitriadwiprasetyaningtyas@mail.unnes.ac.id
}

\begin{abstract}
The goal of this study was to develop, test, and assess the feasibility and usefulness of a web-based ebooklet as a teaching tool for fifth-grade students at SDN Sembaturagung 02. The Borg and Gall research and development $(R \& D)$ paradigm was used in the research. Data was gathered through interviews, observations, documentation, questionnaires, and tests. The findings indicate that webbased e-booklets can be created, are easy to use, and are effective at improving learning outcomes. The purpose of this study was to create, test, and evaluate the feasibility and utility of a web-based ebooklet as a teaching tool for SDN Sembaturagung 02 fifth-grade students. In this study, the Borg and Gall research and development $(R \& D)$ paradigm was used. Interviews, observations, documentation, questionnaires, and testing were used to collect data. The findings show that web-based e-books can be created, are simple to use, and improve learning outcomes.
\end{abstract}

Keywords: E-Booklet, Social Studies, web

\begin{abstract}
Abstrak
Penelitian ini dilakukan dengan tujuan mengembangkan, menguji kelayakan, serta keefektifan $e$ booklet berbasis web sebagai bahan ajar muatan IPS Kelas V SDN Sembaturagung 02. Metode penelitian yang digunakan adalah research and development (R\&D) model Borg and Gall. Teknik pengumpulan data yang digunakan yaitu wawancara, observasi, dokumentasi, angket dan tes. Hasil penelitian menunjukkan bahwa e-booklet berbasis web dapat dikembangkan, layak digunakan, serta efektif meningkatkan hasil belajar. Dinyatakan sangat layak dengan presentase nilai-rata-rata validasi ahli materi sebesar $90 \%$ dan ahli media sebesar $88 \%$, serta memperoleh repson sangat positif presentase tanggapan guru sebesar $95 \%$ dan tanggapan siswa sebesar $82 \%$. Peningkatan rata-rata hasil belajar siswa sebesar 66\% dan hasil uji n-gain sebesar 0,64 dengan kategori sedang. Maka dapat disimpulkan bahwa e-booklet berbasis web dapat dikembangkan, layak digunakan dan efektif meningkatkan hasil belajar siswa kelas V SDN Sembaturagung 02.
\end{abstract}

Kata Kunci: E- Booklet, Ilmu Pengetahuan Ssosial, web 


\section{A. Pendahuluan}

UU nomor 20 tahun 2003 dalam pasal 37 menyatakan IPS sebagai salah satu muatan pembelajaran yang wajib dimuat dalam kurikulum pendidikan dasar. IPS merupakan sebuah bidang studi yang mempelajari, menelaah, serta menganalisis gejala dan masalah sosial dalam masyarakat yang ditinjau dari berbagai aspek kehidupan ${ }^{1}$. Pada jenjang SD/MI IPS memuat materi Geografi, Sejarah, Sosiologi, dan Ekonomi. Tujuan utama pendidikan IPS di Sekolah Dasar adalah mengembangkan potensi siswa untuk peka terhadap masalah sosial dalam masyarakat, memiliki sikap positif, dan terampil dalam mengatasi masalah sehari-hari. ${ }^{2}$

Berdasarkan hasil wawancara dengan guru kelas V SDN Sembaturagung 02 diperoleh permasalahan yaitu siswa mengalami kesulitan dalam menemukan bahan ajar tambahan yang sesuai dengan materi. Siswa kesulitan untuk belajar mandiri menggunakan buku ajar sekolah karena terdapat banyak gambar yang membutuhkan penjelasan. Siswa mengalami kesulitan dalam memahami materi yang belum pernah mereka alami, terutama dalam muatan IPS seperti materi garis lintang dan peristiwa bersejarah. Tidak semua siswa memiliki sarana pribadi dalam pembelajaran daring. Hal ini membuat siswa tidak dapat melaksanakan pembelajaran dalam waktu yang bersamaan sehingga guru mengalami kesulitan dalam menjelaskan ulang materi yang belum dipahami siswa. Menurut guru, dibutuhkan bahan ajar yang menarik dan dapat digunakan siswa untuk belajar mandiri kapan saja, dimana saja, mudah diakses, dan dapat disimpan atau selalu dapat dibuka oleh siswa sehingga bisa dipelajari kembali.

Permasalahan pokok pada kelas V SDN Sembaturagung 02 yaitu terkait bahan ajar muatan IPS materi sejarah. Bahan ajar merupakan bagian dari sumber belajar. Sumber belajar merupakan bahan mentah atau sumber dalam penyusunan bahan ajar yang perlu diolah. ${ }^{3}$ Banyak jenis dan bentuk bahan ajar yang dapat dikembangkan dan digunakan, salah satunya adalah booklet.

Untuk membantu mengatasi permasalahan tersebut peneliti melakukan pengembangan $e$ booklet berbasis web sebagai bahan ajar muatan pembelajaran IPS Kelas V. Hal ini dikarenakan booklet dapat memuat informasi yang lebih banyak dan mudah dipelajari. ${ }^{4}$ Booklet merupakan buku kecil dengan paling sedikit berisi lima halaman namun tidak lebih

\footnotetext{
${ }^{1}$ Suhada, I, Konsep Dasar IPS. Bandung: PT Remaja Rosdakarya, 2017

${ }^{2}$ Nasution, T., \& Lubis, M. A, Konsep Dasar IPS. Yogyakarta: Samudra Biru, 2018

${ }^{3}$ Prastowo, A. Panduan Kreatif Membuat Bahan Ajar Inovatif. Yogyakarta: Diva Press, 2012

${ }^{4}$ Yelviana, Yelviana. Pengembangan Booklet Edukasi Kesehatan Reproduksi Remaja untuk Siswa SMA. Diss. Universitas Negeri Padang, 2019
} 
dari empat puluh delapan halaman yang dihitung di luar sampul. ${ }^{5}$ Untuk memberikan kemudahan akses serta mendukung perkembangan teknologi terutama dalam situasi pembelajaran daring. Booklet dibuat dalam bentuk elektronik dan menjadi e-booklet. Web atau website merupakan kumpulan halaman situs serta dokumen yang tersebar ke seluruh penjuru dunia melalui jaringan internet. ${ }^{6}$ Tujuan dari penelitian ini adalah untuk mengembangkan, menguji kelayakan, serta keefeektifan e-booklet berbasis web dalam pembelajaran IPS kelas V SDN Sembaturagung 02.

Penelitian yang mendukung pengembangan tersebut adalah penelitian oleh Muga, dkk, dalam jurnal tahun 2017 Vol. 01 No. 04 yang berjudul "Pengembangan Bahan Ajar Elektronik Berbasis Model Problem Based Learning dengan Menggunakan Model Dick and Carey". Penelitian tersebut menunjukkan bahwa buku ajar elektronik dapat dibuat dan dikembangkan. ${ }^{7}$ Hasil uji ahli memperoleh hasil dengan kategori sangat baik. Kemudian berdasarkan tanggapan mahasiswa diperoleh hasil buku ajar elektronik berada pada kategori sangat baik.

Penelitian oleh Puspita, dkk, dalam jurnal yang berjudul "Pengembangan Media Pembelajaran Booklet pada Materi Sistem Imun Terhadap Hasil Belajar Siswa Kelas XI SMAN 8 Pontianak" tahun 2017, Vol. 04 No. 01. Hasil penelitian menyatakan bahwa media pembelajaran e-booklet yang dikembangkan adalah valid, praktis, dan efektif digunakan.

Penelitian oleh Suniah, dkk dalam jurnal "Booklet Development Based Research on the Diversity of Insects on Solanaceae as a Suplement of Biology Teaching Materials in High School" tahun 2018, Vol. 07 No. 02. Hasil penelitian menyatakan bahwa booklet berbasis keanekaragaman serangga pada tanaman solanaceae layak digunakan sebagai bahan ajar Biologi di sekolah menengah.

Potensi dan masalah dilakukan dengan melakukan wawancara guru kelas V SDN Sembaturagung 02 dan menggunakan dokumentasi data yang kemudian memperoleh identifikasi masalah yaitu: 1) Siswa kesulitan mentukan bahan ajar tambahan, 2) Siswa kesulitan dalam muatan pembelajaran IPS terutama materi sejarah, 3) Kendala sarana dan

\footnotetext{
${ }^{5}$ Sukmawati, Sari Sri, Eko Nursulistyo, dan Dewi Oktaviyanti. "Pengembangan bahan ajar booklet untuk meningkatkan hasil belajar pokok bahasan momentum untuk siswa kelas X semester 2 SMAN 4 Yogyakarta." Quantum: Seminar Nasional Fisika, dan Pendidikan Fisika. 2018, hlm.55

${ }^{6}$ Batubara, H. H. Pembelajaran Berbasis Web dengan Moodle Versi 3.4. Sleman: Budi Utama, 2018, hlm. 1
} 
waktu pembelajaran daring. Hal ini berpengaruh terhadap pemerolehan hasil belajar siswa kelas V SDN Sembaturagung 02 pada muatan pembelajaran IPS.

Berdasarkan latar belakang permasalahan tersebut, peneliti membatasi masalah tekait kebutuhan bahan ajar muatan pembelajaran IPS. Rumusan masalah dalam penelitian ini yaitu: (1) Bagaimanakah desain pengembangan e-booklet berbasis web sebagai bahan ajar muatan pembelajaran IPS untuk meningkatkan hasil belajar siswa kelas V SDN Sembaturagung 02? (2) Bagaimanakah kelayakan pengembangan e-booklet berbasis web sebagai bahan ajar muatan pembelajaran IPS untuk meningkatkan hasil belajar siswa kelas V SDN Sembaturagung 02? (3) Bagaimanakah keefektifan pengembangan e-booklet berbasis web sebagai bahan ajar muatan IPS terhadap peningkatan hasil belajar siswa kelas V SDN Sembaturagung 02?. Berdasarkan rumusan masalah tersebut, penelitian ini memiliki tujuan yaitu: (1) Mengembangkan bahan ajar berdasarkan desain pengembangan $e$-booklet berbasis web sebagai bahan ajar muatan pembelajaran IPS untuk meningkatkan hasil belajar siswa kelas V SDN Sembaturagung 02; (2) Menguji kelayakan pengembangan e-booklet berbasis web sebagai bahan ajar muatan pembelajaran IPS untuk meningkatkan hasil belajar siswa kelas V SDN Sembaturagung 02; (3) Menguji keefektifan pengembangan e-booklet berbasis web sebagai bahan ajar muatan pembelajaran IPS terhadap peningkatan hasil belajar siswa kelas V SDN Sembaturagung 02.

\section{B. Metode Penelitian}

Penelitian ini menggunakan metode research and development (R\&D) dengan model pengembangan Borg dan Gall. Research and development (R\&D) adalah cara ilmiah yang dilakukan untuk merancang, memproduksi, dan menguji validitas produk yang dikembangkan. ${ }^{8}$ Peneliti menetapkan variabel penelitian berdasarkan judul penelitian "Pengembangan E-booklet Berbasis Web sebagai Bahan Ajar Muatan Pembelajaran IPS untuk Meningkatkan Hasil Belajar Siswa Kelas V SDN Sembaturagung 02 Kecamatan Jakenan Kabupaten Pati". Terdapat dua variabel dalam penelitian ini yaitu satu variabel bebas dan satu variabel terikat. Variabel bebas dalam penelitian ini adalah e-booklet berbasis web sebagai bahan ajar muatan pembelajaran IPS. Variabel terikat dalam penelitian ini adalah hasil belajar muatan pembelajaran IPS siswa kelas V SDN Sembaturagung 02.

\footnotetext{
${ }^{8}$ Sugiyono, Metode Penelitian Pendidikan. Bandung: Alfabet, 2016
} 
Subjek dalam penelitian ini adalah 29 siswa kelas V SDN Sembaturagung 02. Uji coba kecil dilakukan kepada enam siswa kelas V SDN Sembaturagung 01. Sampel ditentukan dengan menggunakan teknik purposive sampling, yaitu pemilihan sampel berdasarkan pertimbangan tertentu. Teknik pengumpulan data yang digunakan yaitu wawancara,

observasi, dokumentasi, angket dan tes. Uji kelayakan dilakukan dengan validasi produk oleh ahli materi dan ahli media. Uji keefektifan dilakukan dengan menganalisis data hasil belajar berupa nilai pre test dan post test. Sebelum digunakan, intrumen tes diuji validitas dan reabilitasnya. Berdasarkan analisis hasil uji coba soal, diperoleh 30 soal yang digunakan sebagai instrument pengukuran hasil belajar. Analisis data hasil belajar dilakukan dengan analisis data awal berupa uji normalitas kemudian analisis data akhir menggunakan statistik parametris berupa uji t dan uji gain untuk mengetahui peningkatan hasil belajar.

Pengumpulan data dilakukan untuk memperoleh informasi sebagai bahan perencanaan produk untuk dapat membantu menjawab permasalahan yang ada. Pengumpulan data dilakukan dengan menggunakan kuisioner atau angket analisis kebutuhan bahan ajar yang akan diisi oleh guru. Hal ini dilakukan agar bahan ajar yang dikembangkan sesuai dengan kebutuhan dalam pembelajaran.

\section{Hasil Dan Pembahasan}

\section{Desain Pengembangan Produk}

Pengembangan e-booklet berbasis web dilakukan dengan mempertimbangkan hasil pengumpulan data, masukan guru kelas, serta angket kebutuhan guru dan siswa. Pengembangan desain dilakukan dengan menyusun materi dan rancangan desain awal menggunkan Microsoft Word 2010. Kemudian desain e-booklet dibuat menggunakan aplikasi Adobe Indesign, Adobe Photoshop, dan Adobe Illustrator. Desain akhir e-booklet dibuat dalam format PDF yang kemudian diunggah ke website Flipsnack dan dilakukan proses pengeditan kembali untuk menambahkan efek suara dan fitur tautan video beserta keterangnya. Setelah melalui proses tersebut maka terbentuklah e-booklet berbasis web. Langkah-langkah yang dilakukan oleh peneliti untuk menyusun e-boooklet berbasis web adalah sebagai berikut:

1. Membuat indikator dan tujuan pembelajaran sesuai materi yang ingin dikembangkan

2. Menyiapkan materi peristiwa lahirnya Pancasila dari berbagai sumber referensi.

3. Membuat soal evaluasi pembelajaran

4. Membuat petunjuk penggunaan buku ajar

5. Mengunduh gambar dan video yang sesuai dengan materi 
6. Mengedit bagian video sesuai kebutuhan dan diunggah ke laman youtube kemudian menyalin link video yang diperlukan

7. Menyusun semua komponen isi dan gambaran lay out e-boooklet menggunakan Microsoft Word 2010.

Page | 112

8. Membuat desain e-booklet menggunakan aplikasi Adobe Indesign, Adobe Photoshop, Adobe Illustrator.

9. Membuat desain e-boooklet menjadi format PDF

10. Proses produksi mengubah desain e-booklet format PDF ke dalam bentuk e-boooklet berbasis web

11. Mengunggah e-booklet format PDF ke website flipsnack dengan menggunakan komputer atau laptop

12. Mengedit tampilan, efek, dan menambahkan link rekomendasi video pembelajaran beserta keterangannya

E-booklet berbasis web sebagai bahan ajar muatan pembelajaran IPS memuat materi peristiwa lahirnya Pancasila. Rancangan dan desain produk meliputi pokok isi buku pada materi peristiwa lahirnya Pancasila, penyusunan naskah, penempatan materi dan gambar, serta evaluasi. Penyusunan e-booklet berbasis materi disesuaikan dengan Kompetensi Inti, Kompetensi Dasar, indikator, dan tujuan pembelajaran. Bagian e-booklet berbasis web terdiri dari: 1) bagian depan berupa sampul, daftar isi, petunjuk penggunaan booklet berbasis web, $\mathrm{KI}, \mathrm{KD}$, indikator, dan tujuan, 2) bagian isi, berupa materi dan evaluasi, 3) bagian penutup berupa daftar pustaka sampul belakang. E-booklet berbasis web di desain dengan ukuran A4 dan sesuai ciri booklet namun dibuat dalam bentuk elektronik dan akan menggunakan web agar mudah diakses, didistribusikan, dan lebih menarik untuk dibaca.

\section{Penilaian Kelayakan E-booklet Berbasis Web}

Penilaian kelayakan dilakukan oleh validator ahli berdasarkan pada angket penilaian yang disusun sesuai kisi-kisi yang disusun berdasarkan Depdiknas 2008 dengan beberapa tambahan dari peneliti. Aspek penilaian kelayakan ahli materi meliputi aspek isi, kebahasan dan sajian. Aspek penilaian ahli media meliputi tampilan (sampul dan isi), keterbacaan, dan penggunaan. Angket penilaian memiliki rentang skor 1-4. Angket penilaian ahli materi dan ahli media memiliki 15 butir pernyataan. Baik ahli media dan ahli materi sama-sama memberikan saran untuk perbaikan e-booklet berbasis web agar layak digunakan dan diuji cobakan. Setelah produk diperbaiki, maka selanjutnya validator ahli melakukan penilaian dari produk tersebut. 
Penilaian kelayakan e-booklet berbasis web materi peristiwa lahirnya Pancasila dilakukan melalui validasi ahli materi dan ahli media. Hasil validasi ahli disajikan dalam tabel 1 .

Tabel 1. Penilaian Kelayakan E-booklet Berbasis Web

\begin{tabular}{ccccc}
\hline Ahli & $\begin{array}{c}\text { Skor } \\
\text { Maksimal }\end{array}$ & $\begin{array}{c}\text { Skor yang } \\
\text { Diperoleh }\end{array}$ & Presentase & Kriteria \\
\hline Materi & 60 & 54 & $90 \%$ & $\begin{array}{c}\text { Sangat } \\
\text { Layak }\end{array}$ \\
Media & 60 & 53 & $88 \%$ & Sangat \\
& & & & Layak
\end{tabular}

Data dalam tabel 1 menunjukkan bahwa e-booklet berbasis memperoleh kriteria sangat layak dengan presentase $90 \%$ dari ahli materi dan $88 \%$ dari ahli media. Maka dapat disimpulkan bahwa e-booklet berbasis web materi peristiwa lahirnya Pancasila layak untuk untuk digunakan dan diuji cobakan setelah melakukan perbaikan sesuai saran masukan validator.

Setelah produk dinilai oleh validator ahli media dan materi maka dilakukan uji kelompok kecil. Uji coba kelompok kecil dilakukan kepada 6-12 siswa. Sampel ditentukan dengan menggunakan teknik purposive sampling, yaitu pemilihan sampel berdasarkan pertimbangan tertentu. Peneliti melakukan uji coba kecil di SDN Sembaturagung 02 dan melibatkan 6 siswa kelas V secara heterogen berdasarkan peringkat kelas, yaitu dua siswa peringkat atas, dua siswa peringkat tengah, dan dua siswa peringkat bawah. Hal ini dilakukan agar $e$-boooklet berbasis web yang dikembangkan peneliti dapat dapat digunakan oleh semua siswa secara merata. Uji coba kelompok kecil dilakukan kepada enam siswa SDN Sembaturagung 01. Tujuannya adalah melihat tanggapan terkait pengunaan e-booklet berbasis web dalam pembelajaran. Siswa dan guru menjadi subjek penilai pada uji coba kelompok kecil dengan mengisi angket tanggapan terhadap penggunaan e-booklet berbasis web.

Uji coba kelompok kecil dilakukan untuk mengetahui kelayakan dan tanggapan siswa serta guru terhadap e-boooklet berbasis web yang dikembangkan oleh peneliti sebelum digunakan untuk uji coba kelompok besar. Siswa dan guru diperkenalkan dengan e-boooklet berbasis web dan menggunakannya untuk pembelajaran kemudian siswa dan guru mengisi angkat tanggapan. Dalam penelitian ini, peneliti mengembangkan bahan ajar yang mudah diakses serta menyesuaikan keadaan pembelajaran yang mengharuskan siswa untuk lebih mandiri dalam belajar. Booklet memiliki cakupan isi materi yang mendalam dan terfokus 
dibantu dengan banyak gambar serta desain yang menarik. Kemudian ditambah penggunaan web dengan fitur tambahan seperti tautan video yang mengarahkan pembaca langsung menuju laman youtube untuk menonton video pembelajaran sesuai materi. Hal ini dapat membuat bahan ajar yang dikembangkan oleh peneliti menjadi berbeda dan lebih inovatif sehingga diharapkan dapat meningkatkan minat dan hasil belajar siswa

Hal ini sejalan dengan penelitian yang dilakukan oleh Amalia ${ }^{9}$, dkk, tahun 2020 Vol. 03 No. 03 dengan judul "Pengembangan E-booklet Berbasis Karakter Kemandirian dan Tanggung Jawab melalui Aplikasi Edmodo pada Materi Bangun Datar". Hasil penelitian menunjukkan bahwa e-booklet valid dan praktis untuk digunakan dengan persentase sebesar 96,74\% untuk validasi materi dan 99,53 untuk validasi media dengan kategori sangat valid, serta kepraktisan dengan presentase $98,82 \%$.

Kemudian penelitian oleh Pratiwi dan Wahyudi ${ }^{10}$ dengan judul "Pengembangan Bahan Ajar Tematik Berbasis Website untuk Siswa di Sekolah Dasar" tahun 2021, Vol. 812, No. 01. Hasil penelitian ini menunjukkan bahwa bahan ajar berbasis website valid dan praktis digunakan dalam pembelajaran siswa kelas IV yang dalam penelitian ini berada di SD Kanisius Cungkup Salatiga. Presentase uji pakar materi yang diperoleh yaitu 75,7\% dan uji pakar bahan ajar sebesar $84 \%$ dengan respon siswa sebesar $90 \%$.

\section{Angket Tanggapan Siswa dan Guru}

Angket tanggapan diberikan kepada siswa dan guru pada tahap uji coba kelompok kecil setelah menggunakan e-booklet berbasis web dalam pembelajaran untuk melihat respon terhadap penggunaan e-booklet berbasis web. Siswa dan guru menggunakan e-booklet berbasis web dalam pembelajaran, kemudian memberikan penilaian dengan mengisi angket tanggapan yang diberikan. Angket tanggapan siswa dan guru disusun berdasarkan kisi-kisi yang terdiri dari aspek isi, penyajian, kebahasaan, dan penggunaan. Jumlah item peryataan pada angket tanggapan siswa adalah 18 item dan 21 item pernyataan untuk angket tanggapan guru.

Uji coba skala kecil dilakukan kepada enam siswa kelas V SDN Semabturagung 01 yang terdiri dari dua siswa laki-laki dan empat siswa perempuan. Siswa uji coba dipilih berdasarkan rasio, yaitu dua siswa pandai, dua siswa sedang, dan dua siswa dengan nilai yang

9 Amalia, N. I., Yuniawatika, T. M., \& Murti, T, Pengembangan E-Booklet Berbasis Karakter Kemandirian Dan Tanggung Jawab Melalui Aplikasi Edmodo Pada Materi Bangun Datar. Jurnal Kajian Teknologi Pendidikan, 3(3), 2020, hlm. 282-291.

${ }^{10}$ Pratiwi, S. I., \& Wahyudi, W, Pengembangan Bahan Ajar Tematik Berbasis Website untuk Peserta Didik di Sekolah Dasar. Edukatif: Jurnal Ilmu Pendidikan, 3(2), 2021, hlm. 333-340. 
kurang. Hal ini dilakukan agar e-booklet berbasis web dapat digunakan oleh semua siswa. Hasil validasi ahli disajikan dalam tabel 2.

Tabel 2. Hasil Angket Tanggapan Siswa dan Guru

\begin{tabular}{ccc}
\hline Respon & Presentase & Kriteria \\
\hline Siswa & $95 \%$ & Sangat Positif \\
Guru & $82 \%$ & Sangat Positif
\end{tabular}

Tabel 2 menunjukkan hasil tanggapan siswa kelas V SDN Sembaturagung 01 termasuk dalam kriteria sangat positif dengan perolehan rata-rata presentase sebesar 95\%. Sedangkan guru kelas V SDN Sembaturagung memberikan tanggapan dalam ketegori sangat positif dengan rata-rata presentase sebesar $82 \%$. Baik siswa maupun guru tidak memberikan catatan tambahan sehingga e-booklet berbasis web dapat langsung digunakan untuk uji coba skala besar. Berdasarkan hasil tersebut dapat disimpulkan bahwa e-booklet berbasis web memperoleh tanggapan sangat positif dan layak digunakan untuk uji coba skala besar.

Uji coba kelompok besar dilakukan untuk menguji keefektifan $e$-booklet berbasis web yang dikembangkan oleh peneliti terhadap peningkatan hasil belajar siswa kelas V SDN Sembaturagung 02 pada materi peristiwa lahirnya Pancasila. Uji coba kelompok besar dilakukan kepada 29 siswa kelas V SDN Sembaturagung 02. Untuk melihat peningkatan hasil belajar dengan menggunakan e-booklet berbasis web, siswa mengerjakan soal pre-tes sebelum menggunakan e-booklet berbasis web dan mengerjakan post-tes setelah melakukan pembelajran menggunakan $e$-booklet berbasis web

Sejalan dengan hasil tanggapan guru dan siswa tersebut, penelitian oleh Yusuf, dkk ${ }^{11}$, tahun 2019, Vol. 07 No. 01, dengan judul "Pengembangan Bahan Ajar Perang Lasem dalam Bentuk Booklet untuk Pembelajaran Sejarah Lokal di SMA Negeri 1 Lasem”. Hasil dari penelitian tersebut menyebutkan bahwa bahan ajar booklet efektif untuk digunakan dalam pembelajaran sejarah lokal di SMA Negeri 1 Lasem. Hal ini berdasarkan data perolehan ratarata presentase ahli materi sebesar $83,26 \%$ dan 77,15 untuk ahli media. Sedangkan tanggapan guru memperoleh presentase sebesar $87,5 \%$ dan $88 \%$ untuk tanggapan siswa.

Kemudian ada penelitian dari Pramestika dan Wahyudi, tahun 2021, Vol. 04, No. 01, dengan judul "Pengembangan Bahan Ajar Tematik Berbasis Website untuk Siswa Kelas V SD". Hasil penelitian tersebut menunjukkan presentase uji ahli sebesar 75,7\% untuk materi dan $84 \%$ untuk bahan ajar. tanggapan siswa memperoleh presentase sebesar $87,8 \%$. Sehingga bahan ajar tematik berbasis web dinyatakan praktis untuk digunakan. 


\section{Keefektifan E-booklet Berbasis Web}

Keefektifan $e$-booklet berbasis web dianalisis berdasarkan hasil belajar siswa berupa nilai pre-test dan post-test yang diperoleh dalam tahap uji coba kelompok besar pada 29 siswa kelas V SDN Sembaturagung 02. Nilai pre-test dan post-test menunjukkan rata-rata nilai sebesar 43 serta $20 \%$ presentase ketuntasan dengan 6 siswa tuntas dan 23 siswa tidak tuntas . Post-test menunjukkan hasil rata-rata nilai sebesar 80 dan $86 \%$ presentase ketuntasan dengan 25 siswa tuntas serta 4 siswa tidak tuntas. Nilai pretest dan postest tersebut kemudian dianalisis menggunakan uji $\mathrm{t}$ dan $\mathrm{n}$ gain. Sebelum melakukan uji $\mathrm{t}$, terlebih dahulu dilakukan uji normalitas dan uji Liliefors. Hasil analisis uji t disajikan dalam tabel 3.

Tabel 3. Hasil Analisis Uji T-test

\begin{tabular}{lccc}
\hline Data & $\mathbf{t}_{\text {hitung }}$ & $\mathbf{t}_{\text {tabel }}(\mathbf{0 , 0 5})$ & Keterangan \\
\hline $\begin{array}{l}\text { Pre-test } \\
\text { Post-test }\end{array}$ & 13,64 & $-1,70$ & Ha diterima
\end{tabular}

Berdasarkan tabel 3 diperoleh hasil $-t_{\text {hitung }}<-t_{\text {tabel }}$ atau $t_{\text {hitung }}>t_{\text {tabel }}$ sehingga Ha diterima dan Ho ditolak. Maka e-booklet berbasis web sebagai bahan ajar muatan pembelajaran IPS efektif untuk meningkatkan hasil belajar siswa kelas V SDN Sembaturagung 02.

Selanjutnya adalah menghitung peningkatan rata-rata hasil pre-test dan post-test melalui analisis uji n gain. hasil analisis uji n gain disajikan dalam tabel 4.

Tabel 4. Hasil Analisis Uji N Gain

\begin{tabular}{ccccc}
\hline $\begin{array}{c}\text { Rata-rata } \\
\text { Pre-test }\end{array}$ & $\begin{array}{c}\text { Rata-rata } \\
\text { Post-test }\end{array}$ & $\begin{array}{c}\text { Selisih } \\
\text { rata-rata }\end{array}$ & N-gain & Kriteria \\
\hline 43,17 & 80 & 36,82 & 0,64 & Sedang \\
\hline
\end{tabular}

Berdasarkan tabel 4 diperoleh hasil rata-rata pre-test sebesar 43,17, rata-rata post-test sebesar 80, dan selisih rata-rata sebesar 36,82. Berdasarkan perhitungan tersebut maka diperoleh n-gain sebesar 0,64 dan masuk dalam kriteria sedang karena berada dalam interval $0,3 \leq \mathrm{N}$ gain $<0,7$. Sehingga dapat disimpulkan bahwa e-booklet berbasis web efektif digunakan untuk meningkatkan hasil belajar siswa kelas V SDN Sembaturagung 02 pada muatan pembelajaran IPS materi peristiwa lahirnya Pancasila.

Hasil penelitian tersebut relevan atau sejalan dengan hasil penelitian oleh Hoiroh dan Isnawati yang berjudul "Pengembangan Media Booklet Elektronik Materi Jamur untuk Meningkatkan Pemahaman Konsep Siswa Kelas X SMA” tahun 2020, Vol. 09, No. 01. Hasil 
dari penelitian ini menunjukkan bahwa booklet elektronik valid, praktis, dan efektif digunakan dalam pembelajaran. Hasil kepraktisan rata-rata 97,5\%, n-gain sebesar 0,75, respon siswa $82,5 \%$, dan validasi media memperoleh nilai sebesar 3,94.

Kemudian ada penelitian oleh Utami, dkk, tahun 2020, Vol. 04, dengan judul penelitian "Pengembangan Media Pembelajaran Berbasis Website Tema 6 Subtema 1 Kelas IV". Hasil dari penelitian tersebut menyebutkan bahwa media pembelajaran berbasis website layak digunakan untuk tingkat SD. Hal tersebut berdasarkan perolehan persentase ahli materi sebesar $80 \%$, ahli media $91 \%$, dan ahli bahasa $82,6 \%$. Uji kepraktisan diperoleh $91,2 \%$ dari guru dan sebesar $91,7 \%$ dari siswa.

Berdasarkan analisis penelitian yang dilakukan peneliti serta hasil penelitian yang mendukung, dapat disimpulkan bahwa e-booklet berbasis web efektif digunakan dalam pembelajaran meningkatkan hasil belajar siswa kelas V SDN Sembaturagung 02 pada muatan pembelajaran IPS materi peristiwa lahirnya Pancasila.

\section{Simpulan}

Berdasarkan analisis data dalam penelitian ini, maka diperoleh kesimpulan yaitu: (1) e-booklet berbasis web dinyatakan sangat layak dengan presentase penilaian $90 \%$ dari ahli materi dan $88 \%$ dari ahli media, (2) guru beserta siswa memberikan tanggapan sangat positif terhadap penggunaan e-booklet berbasis web dengan presentase $82 \%$ untuk tanggapan guru dan 95\% untuk tanggapan siswa, (3) e-booklet berbasis web efektif digunakan berdasarkan uji $t$-test dengan hasil $-\mathrm{t}_{\text {hitung }}(-13,64)<-\mathrm{t}_{\text {tabel }}(-1,70)$ maka Ha diterima serta uji $n$-gain dengan hasil sebesar 0,64 yang termasuk kategori sedang. Sehingga dapat dinyatakan bahwa e-booklet berbasis web materi peristiwa lahirnya Pancasila layak dan efektif digunakan pada muatan pembelajaran IPS materi peristiwa lahirnya Pancasila kelas V SDN Sembaturagung 02 karena dapat meningkatkan hasil belajar. 


\section{DAFTAR PUSTAKA}

Amalia, N. I., Yuniawatika, T. M., \& Murti, T, Pengembangan E-Booklet Berbasis Karakter Kemandirian Dan Tanggung Jawab Melalui Aplikasi Edmodo Pada Materi Bangun Datar. Jurnal Kajian Teknologi Pendidikan, 3(3), 2020

Batubara, H. H. Pembelajaran Berbasis Web dengan Moodle Versi 3.4. Sleman: Budi Utama, 2018.

Hoiroh, A. M. M., \& Isnawati, Pengembangan media booklet elektronik materi jamur untuk meningkatkan pemahaman konsep siswa kelas X SMA. BIOEDU Berkala Ilmiah Pendidikan Biologi, 9(1), 2020

Muga, W., Suryono, B., \& Januarisca, E. L, Pengembangan Bahan Ajar Elektronik Berbasis Model Problem Based Learning Dengan Menggunakan Model Dick and Carey. Journal of Education Technology, 1(4), 2017.

Nasution, T., \& Lubis, M. A, Konsep Dasar IPS. Yogyakarta: Samudra Biru, 2018

Pramestika, L. A., \& Wahyudi, W, Pengembangan Bahan Ajar Tematik Berbasis Website untuk Peserta Didik Kelas V SD. Jrpd (Jurnal Riset Pendidikan Dasar), 4(1), 2021

Prastowo, A. Panduan Kreatif Membuat Bahan Ajar Inovatif. Yogyakarta: Diva Press, 2012

Pratiwi, S. I., \& Wahyudi, W, Pengembangan Bahan Ajar Tematik Berbasis Website untuk Peserta Didik di Sekolah Dasar. Edukatif: Jurnal Ilmu Pendidikan, 3(2), 2021

Puspita, A., Kurniawan, A. D., \& Rahayu, H. M, Pengembangan Media Pembelajaran Booklet Pada Materi Sistem Imun Terhadap Hasil Belajar Siswa Kelas Xi Sman 8 Pontianak. Jurnal Bioeducation, 4(1), 2017

Sugiyono, Metode Penelitian Pendidikan. Bandung: Alfabet, 2016

Sukmawati, Sari Sri, Eko Nursulistyo, dan Dewi Oktaviyanti. "Pengembangan bahan ajar booklet untuk meningkatkan hasil belajar pokok bahasan momentum untuk siswa kelas X semester 2 SMAN 4 Yogyakarta." Quantum: Seminar Nasional Fisika, dan Pendidikan Fisika. 2018.

Yelviana, Yelviana. Pengembangan Booklet Edukasi Kesehatan Reproduksi Remaja untuk Siswa SMA. Diss. Universitas Negeri Padang, 2019.

Suhada, I. Konsep Dasar IPS. Bandung: PT Remaja Rosdakarya, 2017

Sukmawati, S. S., Nursulistyo, E., \& Oktaviyanti, D, Pengembangan bahan ajar booklet untuk meningkatkan hasil belajar pokok bahasan momentum untuk siswa kelas X semester 2 SMAN 4 Yogyakarta. Prosiding Seminar Nasional Quantum, Pendiidkan Fisika UAD, $25,2018$. 
Suniah, Indriyanti, D. R., \& Dewi, N. K. (2018). Booklet Development Based Research on the Diversity of Insects on Solanaceae as a Suplement of Biology Teaching Materials in High School. Journal of Innovative Science Education, 7(2), 2018

Utami, R. S., Aji, S. D., \& Chrisyarani, D. D, Pengembangan Media Pembelajaran Berbasis Website Tema 6 Subtema 1 Kelas IV. In Prosiding Seminar Nasional PGSD UNIKAMA, 4(1), 2020

Yusuf, M., Saraswati, U., \& Ahmad, T. A, Pengembangan Bahan Ajar Perang Lasem Dalam Bentuk Booklet Untuk Pembelajaran Sejarah Lokal Di Sma Negeri 1 Lasem. Indonesian Journal of History Education, 7(1), 2019

Yelviana, Y. Pengembangan Booklet Edukasi Kesehatan Reproduksi Remaja untuk Siswa SMA (Doctoral dissertation, Universitas Negeri Padang), 2019 